\title{
Association of psychosocial-spiritual experiences around childbirth and subsequent perinatal mental health outcomes: an integrated review.
}

CROWTHER, S., STEPHEN, A. and HALL, J. 


\begin{abstract}
Background: Perinatal mental health is a substantial concern for women, families, communities and maternity care providers internationally. However, there is little understanding of poor perinatal maternal mental health and association with women's experiences of childbirth. Further understanding of psychosocial-spiritual experiences in childbirth and subsequent perinatal mental health is required.
\end{abstract}

Aim: To systematically identify and synthesise the range of evidence available on psychosocial-spiritual experiences around childbirth and foreground possible associations with subsequent perinatal mental health outcomes.

Method: Integrated analysis of a range of literature types including experimental, nonexperimental and theoretical was undertaken. A comprehensive search strategy was created, and nine databases were searched from 2000-2018. Defined inclusion and exclusion criteria were applied independently by two reviewers. Critical appraisal was carried out independently by two reviewers and a third reviewer was brought in to resolve differences. The Ecology of Childbirth conceptual framework guided the review.

Findings: Six articles were included and four synthesised themes were developed: relationships and kinship matter; significance of childbirth and spiritual experiences; honouring spiritual growth and wellbeing, and physical manifestations and embodiment. Discussion of the themes using the Ecology of Childbirth framework highlight new perspectives and reveal phenomena lying within and beyond childbirth experiences that may influence perinatal mental health. A new conceptual model is proposed.

Conclusions: New insights highlight a paucity of research in the area of perinatal mental health and psychosocial-spiritual childbirth experiences. Further research needs to include 
postnatal mood disorders and the possible associations with psychosocial-spiritual experiences.

Key words: Postnatal depression, Psychosocial factors, Emotional Childbirth, Perceptions

\section{Introduction}

Perinatal mental health is topical and is a substantial concern for maternity care providers globally and informs drivers for maternal health policy, professional guidance and education (Clarry \& Carson, 2018; Howard, Megnin-Viggars, Symington, \& Pilling, 2014; Jones, Cymru, \& O’Leary, 2018; Maternal Mental Health Alliance, 2016; MBRRACE-UK, 2015; NICE, 2014; NMC, 2010; RCM, 2015; Ross-Davie, Elliott, Sarkar, \& Green, 2006). (Note MBRACE-UK is the acronym for Mothers and Babies: Reducing Risk through Audits and Confidential Enquiries in the UK, NICE is National Institute of Clinical Excellence). Depression and anxiety are the most common mental health problems in maternity, with approximately $12 \%$ of women experiencing depression and $13 \%$ experiencing clinical anxiety at some point; many women experience both. It is estimated that $15-25 \%$ of women during the childbirth year are affected by poor mental health (MBRRACE-UK, 2015; NICE, 2014). This appears to be increased in developing countries (WHO, (undated)). Depression has been ranked globally as the most significant disease burden for women between the ages of 15 and 44 years (Bergman, Sarkar, Glover, \& O'Connor, 2010). Yet despite guidance at professional and policy level, the experiences and multi-factorial causes of poor maternal mental health and how to address this phenomenon remain unclear.

This integrated review contributes to further understanding about the experience and causality of perinatal mental health and identifies positive actions and care that may mitigate poor perinatal mental health. The aim is to systematically map, identify and synthesise the 
range of evidence available on psycho-social and spiritual experiences of the antenatal period, labour and birth and foreground possible associations with subsequent perinatal mental health outcomes.

\section{Conceptual framework}

The theme of this literature review is broad and a coherent conceptual framework that addresses the multi-layered complexity of the phenomenon being examined was required. The Ecology of Childbirth conceptual framework (Crowther, 2017), emphasises the relationship of individuals to each other, themselves and the environment (figure 1). The framework includes six parts: contextuality, embodiment, relationality, temporality, spatiality and mystery. Mystery identified in this framework proffers a frame of reference to orientate the review to aspects of childbirth birth that are rarely explored and articulated. The ecology of childbirth conceptual framework therefore helped review the literature through a holistic lens that foregrounded a non-fragmented understanding of childbirth.

Position of figure 1: Ecology of birth (Author one, 2017). Reprinted here with permission $11^{\text {th }}$ April 2019

\section{Methodology}

The study took the form of an integrated review to include analysis of a range of literature types including experimental, non-experimental and theoretical in their approach to more fully understand the topic of interest (Aveyard, Payne, \& Preston, 2016). Two questions were developed for the review to systematically map, identify and synthesise the range of evidence available on psycho-social and spiritual experiences of childbirth. 
(i) What are the psycho-social and spiritual experiences of mothers during antenatal period and childbirth?

(ii) What are the effects of psycho-social and spiritual experiences of women during antenatal period, and childbirth on postnatal wellbeing and mental health?

\section{Search strategies}

Databases searched for evidence were CINHAL, MEDLINE, MIDIRS, PsychARTICLES, Science Direct, OpenDissertations, DART Europe, EThOS and the Cochrane Library. Searching was limited to identify papers published between 2000 and 2018. 2000 was chosen to ensure contemporariness and hand searching of reference lists of included studies. See box 1 for the key search terms. References were saved and shared through a RefWorks database and Dropbox folder.

Position of Box 1: Search terms

Position of Box 2: Inclusion and exclusion criteria

Inclusion and exclusion criteria were set to facilitate study selection (Box 2). Types of studies were of both qualitative or quantitative design, including, for example, phenomenology, ethnography, grounded theory, case study, randomised controlled trial, cohort study, case control study, regression analysis, and realist evaluations. Two reviewers (AIS, SC) carried out the database searches, and to ensure methodological rigour they both independently screened titles, abstracts and full text of selected articles for eligibility. A third reviewer (JH) was consulted in cases where reviewers disagreed. The PRISMA (figure 2) statement guided the study selection process (Moher, Liberati, Tetzlaff, \& Altman, 2009). Seven papers were selected on screening and a further paper was excluded during data extraction because the participants of the study were not within our original inclusion criteria. 
Position of Figure 2: PRISMA flow chart

Two reviewers (AIS and SC) assessed risk of bias and study quality independently. A third reviewer $(\mathrm{JH})$ provided arbitration on disputed aspects. For qualitative studies $(\mathrm{n}=3)$ the Joanna Briggs Institute (JBI) checklist for qualitative and interpretive and critical research was used (Aromataris \& Munn, 2017). Quantitative studies $(n=2)$ were appraised using the Cochrane Pregnancy and Childbirth Group data extraction and appraisal form. One mixed method study was included for which both the qualitative and quantitative tools were used. Six articles were included in the final evidence synthesis.

\section{Process of data extraction and synthesis}

A critical interpretive analysis technique was used to synthesise the findings of materials reviewed (Dixon-Woods et al., 2006). The aim of synthesis was to produce a plausible theoretical account of the domain grounded in the 6 included papers. Quantitative findings when not already converted into words were changed into word descriptions in order to facilitate synthesis (Aromataris \& Munn, 2017). Whittlemore and Knafl (2005) recommend a process data reduction which involves techniques of extracting and coding data from primary sources to simplify, abstract, focus, and organize data into a manageable framework. This involved detailed reading of papers and extraction of key data enabling identification of recurring themes and early critiquing of the content of articles. The themes and subthemes were then subjected to quality assessment to improve the trustworthiness of the synthesis through each member of the review team independently checking the extracted data and synthesis. Bias was reduced through use of a third reviewer during this stage to both check the outcome of decisions and arbitrate between divergent opinions of the two primary reviewers for each paper. One reviewer was neither a midwife or engaged in any research related to childbirth or mental health. This helped ensure avoidance of prejudgements and 
professional orientation to the topic but did not interfere with the process of the review. The process was guided by three steps advocated by Noblit, Hare and Hare (1988):

1. Reciprocal translational analysis (RTA). The key metaphors, themes, or concepts in each study report were identified. An attempt was then made to translate the concepts into each other. Judgements about the ability of the concept of one study to capture concepts from others were based on attributes of the themes themselves, and the concept that was "most adequate" chosen. This included converting numerical findings into words, using original author words when available then synthesising with the findings of the review overall.

2. Refutational synthesis. Contradictions between the study reports were characterised, and an attempt made to explain them. The purpose was to expose knowledge that may be obvious yet not stated and notice when bias in studies and use of author(s) language covered over something of significance to the review.

3. Lines-of-argument synthesis (LOA). This involved building a general interpretation grounded in the findings of the separate studies through an iterative process. The themes or categories that were most powerful in representing the entire dataset were identified by constant comparisons between individual accounts. This constant comparison of theoretical constructs, patterns, themes and variations in the data allowed specification of the categories of analysis and the relationships between them (Whittemore \& Knafl, 2005). By noting patterns, commonalities, themes, clusters, contrasts and comparisons, relationships, chains of evidence, intervening factors and confounding factors we were able to generate a richer theoretical framework and appreciate the complexities across multiple styles of research methodologies and their findings individually and together (Dixon-Woods et al., 2006). Any conflicting or unresolved questions, including our individual and collective analytical hunches were foregrounded as these were recognised as a call to further questioning. 
We ensured throughout that data confirmed the findings and our summation of the synthesis. The iterative process involved deconstruction and restructuring of themes until consensus was achieved. For example, the fourth theme of 'Physical manifestations and embodiment' had not been identified as a distinct theme in of itself in an early iteration. Once JH noted this omission, the team concurred with this insight when re-reading the data and the synthesised theme was added.

Although findings may not be completely reproducible, they are critically appraised and reflect the available evidence using a sustained focus on searching and foregrounding divergent and convergent insights. Conclusions were consistently grounded in the evidence. Our focus remained broad and orientated towards clarity of understanding and generation of new insights using the ecology of childbirth conceptual framework.

\section{Findings}

Although the process of data synthesis was dynamic, interactive and procedurally unbounded it required constant reflexivity to ensure our authorial voices and our conceptual positioning were explicit. The data extraction and subsequent synthesis is reported below in a series of tables:

\section{i. Table one. Summary of descriptive characteristics of the 6 included studies}

ii. Table two. Methodological characteristics of the 6 included studies

iii. Table three. Themes represented across the 6 included studies

iv. Tables 4a-d present the thematic findings with supporting data

These tables show how the data was converted from the extracted data of individual sources into displays that assemble the data from multiple primary sources around particular synthesised themes.

Table one: Summary of descriptive characteristics of the included studies 
(Position of table 1)

Table two: Methodological characteristics of included studies

(Position of table 2)

Table three: Themes represented across the 6 included studies

(Position of table 3)

The aim was to maximise relevance to the review purpose and provide useful theoretical contributions. Tables’ 4a-4d present the thematic findings, each named following our interpretation and synthesis of the data.

Table 4a. Synthesised theme: Relationships and kinship matter

(Position of table 4a)

Table 4b. Synthesised theme: Significance of childbirth and spiritual experiences

(Position of table 4b)

Table 4c. Synthesised theme: Honouring spiritual growth and wellbeing

(Position of table 4c)

Table 4d. Synthesised theme: Physical manifestations and embodiment

(position of table 4d) 


\section{Discussion}

In discussing the four synthesised themes, we return to the conceptual framework of the ecology of childbirth (figure 1) and explore each of the six parts of the framework in relation to the four synthesised themes of this review.

\section{Contextuality}

Contextuality was strongly evidenced throughout the six included papers and four idenfied themes highlighting the diversity of cultures and cosmologies (e.g. religious and creation belief systems). In some of the papers there appears to be a fascination with difference and the exotic especially when contrary to westernised birthing practices. However, this difference does bring into relief something of significance. Dietsch et al (2011) dramatically highlights the importance of the context of care provision and how, when this is insensitive, emotional distress can ensue. Hanely and Brown (2014) emphasise the need to honour the cultural context and spiritual practices of individuals and communities. Cultures in which abstract reasoning inform cosmological understanding and associated beliefs, values and practices are often in sharp contrast with the scientific reasoning that informs much western biomedical maternity practices. This divergence enables us to see into different ways of understanding birth contextually, that is beyond our everyday points of reference.

Conversely, what became apparent was how such divergent cultures contributed to the final convergent themes, which resonated across cultures and geographical regions. The context in which childbirth unfolds includes cultural and spiritual qualities, people (family and care providers), places of care and how care is delivered. It is evident that context of childbirth experiences will always have influence on childbirth moods. 


\section{Spatiality}

Although spatiality was not overtly a named theme in the review it was revealed through all four themes. Bennington (2010) describes different levels of energy through these childbirth experiences, namely - environmental energy; place and space of birth and the socio-cultural milieu that surrounds birth and how contextual particularity is crucial and needs to be honoured and balanced. Bennington also describes the individual energy as the woman connects with (or not) her own energy. Mitchell's (2012) study highlights women's need to find space within their childbirth experience to relax and integrate their experiences. Unsurprisingly the physical place of birth was also highlighted as significant. Two women in the Dietsch et al (2011) study were disturbed by the mood permeating some birth rooms, one expressing concern that the place was 'haunted'. In the same study women reported being emotionally distressed on admission to the hospital because of the feelings of separation from the familiar and the abusive treatment they received whilst there. It is apparent that receiving unkind care in an unfamiliar environment opens a space of isolation and fear. Unfortunately, disrespectful care occurs, and this has been described elsewhere (Birthrights, 2013; Bohren et al., 2015; Kirkup, 2015). Although this review is not focussed on place of birth it highlights how the mood of a place influences the perceptions of experience about places where childbirth care is undertaken; experiences previously recognised (Crowther, Smythe, \& Spence, 2014). When considering how moods of a place can influence a woman's affective wellbeing it is important to acknowledge how the felt space in which childbirth care takes place attunes in a way that enables experiences to be positive, respectful and affirming.

\section{Embodiment}

The significance of embodiment as part of spiritual wellbeing was revealed through the theme of physical manifestation and embodiment in three of the studies. Maternity care 
providers need to be cognizant of the physical and emotional needs of childbearing women. Brinkley (2004) and Hanely \& Brown (2014) show how rest and sleep are important to consider because not attending to physical needs, such as sleep, increases stress and may lead to lower moods postnatally. Brinkley (2004) also found that neglecting physical needs interferes with relationships and the ability to adapt to the changes occurring through childbirth. According to Hanely \& Brown (2014), the risk of this occurring increased when there were other factors such as lack of familial support, poverty and a traumatic birth. Mitchell (2012) found that physical connection and touch was important. Her study highlights how women respond to sensitive touch because this helps them keep connected and 'in' their bodies. Mitchell contends that embodied connection may enable integration of the experiences of childbirth and nurture possibility for spiritual growth. This is akin to Parrett and Fahy's (2008) work that describes how a woman can access her own coping strategies, often strategies that she was not aware of prior to birthing that help her experience spiritual wellbeing.

Further, this can be related to behaviours that influence the health and physical wellbeing of the childbearing woman and infant(s). Jesse and Reed (2004) suggest that foregrounding and acknowledging spirituality and psychosocial wellbeing through pregnancy relates to improved lifestyle choices, such as smoking cessation. It is therefore imperative from a public health perspective that we address physical manifestation and embodiment. Childbirth spiritual experiences are integrated for spiritual growth to occur and staying embodied through childbirth may open potential for such growth. To ignore the significance of embodied experiences could potentially leave women at risk of emotional morbidity. 


\section{Relationality}

Equally crucial is the quality of relationality that is woven through childbirth. Relationships and kinship matter and were major themes that resonated across all six studies. No other theme in this review traversed all included studies. Brinkley (2004) study found that women require help to self-care to maintain balance for interpersonal relationships to flourish and reported how poorer interpersonal relationships are associated with decreased opportunity for spiritual growth. The Hanely \& Brown (2014) study revealed how connection with close relatives, particularly the partner (stated as husband in the study) is important to wellbeing and feeling spiritually safe. They found that women who felt alone, disconnected, uncared and supported by kin were left feeling powerless and helpless. Likewise, Lundgren (2002) highlights the importance of an anchoring companion (i.e. midwife) at birth because this enables the woman to release into her experience. This resonates with the findings of Mitchell’s (2012) study in which the style of care others provide invokes transformation of experiences illustrating 'how' we are with women is crucial not just what we 'do'. Attitude of the caregiver is therefore significant. The caregiver who is respectful and is "sensitive, caring, kind, skilled, and competent” will lead a woman to experience a more positive birth experience (Oladapo et al 2018). As Lundgren (2002) shows trusting relationships with care providers helps nurture wellbeing through helping a woman to feel a sense of relief in the safety of that support that is there for her, as well as strengthening her self-confidence. In Brinkley's study this effect appears more pertinent the higher the parity.

In Hanely and Brown's study, the reported symptoms of Jinn possession were similar to the identified symptoms in western biomedical postnatal mood disorders. Hanely and Brown found that Jinn possession symptoms could be mitigated through positive connections to others. Moreover, the findings from Mitchell’s (2012) study infer that relational connectedness does improve wellbeing. This implies that trusting relationships are significant 
and help a woman feel understood and seen as a whole person facilitating positive birth experience and better relationships with her infant. It could be construed that this facilitates more positive postnatal moods.

Both Mitchell (2012) and Bennington (2010) stress the transformative energy as woman and infant come together and how the time of bonding/attachment is built upon foundations already laid down in the perceptions of positive birth experience. The Bennington (2010) study suggests that perceived birth experience has a stronger correlation and influence on maternal infant bonding than found with spirituality alone. How positive perceptions of birth experience are associated with better bonding with infants is not clear, though women in a different study discuss the meaningful transformation and connecting relationship created with the baby during birth (Callister and Khalaf 2010). In addition, further research has suggested links between good childbirth experiences and feeling more positive about being a mother, with less anxiety and stress around the role (Takehara et al 2009). Dietsch et al's (2011) study clearly shows how childbirth experiences are relational and those that are culturally and individually abusive can lead to potential for emotional morbidity. The protective effect of strong kinship and trusting relationships with care providers has been previously demonstrated (Davis-Floyd, 2017; Farry \& Crowther, 2014; Kitzinger, 2012). Cultural safety is concerned with relationships and is crucial in maternity care. The data in this review shows how psychosocial stressors are related to poor interprofessional working. Lack of value given to kinship and trusting culturally safe relationships around childbirth is detrimental and may result in stress that affects post-partum mood. It is evident that relationships matter and that cultural insensitivity and discordant interpersonal relationships around childbirth are harmful and may lead to spiritual distress and affect postpartum mood. 


\section{Temporality}

Temporality is part of childbirth experience and is comprised of clock time and felt-time. However, this distinction can cause tension in contemporary maternity care. The theme honouring spiritual growth and wellbeing resonates with the importance of felt-time and the tension with clock time. Women spoke of how they need time to adapt, to attend to their own needs, and how they could feel rushed by the time measured protocols and institutional routines when in labour. In Lundgren’s (2002) work women needed time to contemplate past, current and future relationships. In Lundgren's study childbirth was revealed as a special time requiring internal transformation that calls women to come into themselves. Being called to be externalised prematurely could be interrupting this 'going within' process of transformation and hinder emotional wellbeing. Mitchell’s (2012) study highlights how women seek desperately to find time for themselves to integrate what is happening to them through the unpredictability of the childbirth year. Mitchell's study reveals how time is required to address spiritual wellbeing and how respecting the need for this time may reduce risk and need for biomedical interventions. If spirituality is concerned with meaning making and sense of purpose than the importance of respecting the felt-time nature of childbirth honours the meaning making for women. Other research recognises this spiritual quality of time in and around birth and how this needs to be treated with respect (e.g. Callister \& Khalaf, 2010; Crowther, Smythe, \& Spence, 2015; Delaporte \& Martin, 2018; Hall, 2016; Lemay \& Hastie, 2017; Moloney \& Gair, 2015; Pembroke \& Pembroke, 2008). It is plausible that policies and models of care based on clock time that lack respect for this integrating work can interrupt this quality of felt-time around childbirth leaving leave women vulnerable to perinatal mental mood disorders. 


\section{Mystery}

All six studies acknowledge spirituality as part of childbirth, either as significant experience and/or opportunity for spiritual growth. The review highlighted how connection to the ineffability of childbirth could be manifested through relationship to divinity (in whatever form that took) and brought a sense of magic and feeling of connectivity to something greater than the self. Self-transcendence appeared to occur in which women could reach and extend beyond worldly everyday concerns and experience meaningful moments that were satisfying and fulfilling. The theme, Significance of childbirth and spiritual experiences, highlights how cultural and spiritual practices need to be honoured because they are central to a woman's understanding about childbirth and help bring meaning to her experience.

Hanely and Brown (2014) found childbirth to be more than a biomedical experience and that something beyond westernised maternity care interpretations was occurring, a finding that concurs with the work of Callister and Khalaf (2010). Participants in the Hanely and Brown study highlighted moods that were personified as malevolent spirit and how the influence of malevolent others affected their postnatal emotional and spiritual wellbeing. Childbirth can be understood as a time of spiritual vulnerability in which complications can cause malevolent otherness when there is lack of adherence to cultural taboos and practices. Likewise, Dietsch et al (2011) show how childbirth is experienced as spiritually and psychosocially unsafe when disconnected from beliefs and values. They highlight how anxiety can be caused through non-adherence to local beliefs and practices leading to emotional morbidity and feelings of unsafeness and vulnerability. Brinkley (2004) also foreground the significance of cultural cosmologies and spiritual practices and highlight the potential to harm women when these beliefs and practices are undermined or rejected by others. In addition, Dietsch et al noted that women were empowered when they had a choice 
to adhere or reject these practices. Childbirth can be unpredictable and outcomes uncertain, navigating these experiences requires that a woman's beliefs and values be honoured.

Lundgren (2002) suggest that childbirth is marked by a time of transitions in which care provision needs to be congruent with the woman's own beliefs and values in order to guide women through a process involving releasing and relieving encounters. Mitchell (2012) further emphasised the importance of finding care providers who resonate with one's own worldview to avoid being left feeling vulnerable and bereft of the type of support and guidance needed. Mitchell contends that finding the right support and guidance can mitigate the unpredictability of childbirth experiences providing reassurance, help and peace of mind. This speaks of a quality of relational care that Lundgren refers to as stillness and presence that facilitates positive transformations through a woman's childbirth experiences.

Bennington (2010) define spirituality as an awareness of purpose, meaning in life, sense of connectedness and awareness of a pervasive creative force and highlight how perception of birth (POB) experiences are important and may be influenced by spirituality. However, it is not clear in their study how POB and spirituality can be separated. What is evident is that the significance of POB is associated with spirituality in some way that influences parenting and in turn may be influencing postnatal moods. What is evident in this review is that childbirth is a transitional time overflowing with transformations, existential meaning that touches a feeling of mystery that is reflected in the wider literature (Delaporte \& Martin, 2018; Lahood, 2007e.g. ; Wojtkowiak \& Crowther, 2018).

\section{A new conceptual model}

This review enhances the everyday understanding of childbirth and reveals to us phenomena that lie within and beyond spoken childbirth experiences. Remaining firmly with one perspective and providing scientific reasoning only serves to inhibit our ongoing explorations 
of childbirth. Orem (2001) identifies three components comprising our wellbeing; contentment, pleasure, and happiness. These relate to spiritual experiences that influence normalcy, balance, and sense of purpose and meaning in life. It is plausible that childbirth experiences affect a woman's overall state of health and emotional wellbeing. Orem's conceptual analysis provides an opportunity to think more widely about childbirth beyond the narrow biomedical focus. From the four themes identified in this review and subsequent interpretation, using the ecology of childbirth framework, a new conceptual model has emerged (see figure 3).

Position of Figure 3: Findings presented in the form of a conceptual model

The conceptual relationships in this new conceptual model highlight a level of vulnerability inherent in childbirth. The importance of the models' constituent parts when left unattended and unacknowledged could be leaving women vulnerable to varying degrees of emotional morbidity. However, caution is needed in claiming any causation or indeed association. Although this review has not established robust proof of any association (that is not our intention) it can be construed that moods around birth are influenced by the themes presented in this review. The new conceptual model illuminates an array of influences on postnatal mood disorders inviting another perspective.

Each of the four themes deserve attention in future studies, for example, the significance of personal embodiment and the impact on birth experience, exploring the concept of time to women during labour and birth and the importance of nurturing quality relational continuity in and around childbirth. The findings have immediate implications for maternity care practice in terms of 'how' we set up systems of care and provide care, as well as 'how' we deliver education (to health care providers and parents) in terms of personal and cultural 
safety. We suggest that this is where future research on postnatal mood disorders needs to focus more attention.

\section{Strengths and Challenges}

This review followed a robust process through identification of a clear aim for the study and identification of a conceptual framework. The conceptual framework enabled testing of the themes in relation to existing understanding and provided strength to synthesis and interpretation and building of the subsequent new conceptual model. The experienced research team worked independently on study selection and appraisal and came together collaboratively on all aspects of the review. This involved identifying and interpreting the terms and language used to describe the phenomenon in the literature and comprehending the myriad methodologies in the selected papers during data extraction and interpretation of findings. In addition, no study specifically addressed the questions posed for this review and several readings of each article was required prior to inclusion. The inclusion of unpublished literature may be a limitation of the review. However, rather than standing against published studies from which original data were unavailable, the inclusion of unpublished material may enable communication with a wider audience (Aromataris and Munn 2017).

\section{Conclusion}

This review proffers a critical analysis and synthesis of the literature that informs further thinking and generates provocative research questions for the future despite being the review of previous research. We brought different questions to the available literature and examined subsequent extracted data using a specific conceptual framework. We have integrated existing ideas with fresh insights through synthesising research together to focus on core issues and produced a new conceptual framework through emersion in the topic and related issues. This review has highlighted existing deficiencies in the available literature revealing a 
paucity of focus on postnatal mood disorders and childbirth other than known associations with predisposing risk factors such as pre-existing mental health concerns. We recognise that there will be other individual contexts that will be factors influencing this development and that the answers to this issue will be multifactorial. However, this review contributes possible explanations that need further inquiry and provides stimulus to think differently and ask different research questions.

References

Aromataris, E., \& Munn, Z. (2017). Joanna Briggs Institute Reviewers' Manual. J The Joanna Briggs, 299.

Aveyard, H., Payne, S. A., \& Preston, N. J. (2016). A post-graduate's guide to doing a literature review in health and social care: Oxford University Press.

Bennington, L. (2010). The relationship among maternal infant bonding, spirituality, and maternal perception of childbirth experience. (PhD), Virginia Commonwealth University, Richmond, Virginia.

Bergman, K., Sarkar, P., Glover, V., \& O'Connor, T. G. J. B. p. (2010). Maternal prenatal cortisol and infant cognitive development: Moderation by infant-mother attachment. 67(11), 1026-1032.

Birthrights. (2013). Dignity in Childbirth: the Dignity Survey 2013: Women's and Midwives' Experiences of Dignity in UK Maternity Care. In: Birthrights London.

Bohren, M. A., Vogel, J. P., Hunter, E. C., Lutsiv, O., Makh, S. K., Souza, J. P., . . Tunçalp, Ö. J. P. m. (2015). The mistreatment of women during childbirth in health facilities globally: a mixed-methods systematic review. 12(6), e1001847.

Brinkley, R. L. (2004). The correlation between perceived stress and health promoting selfcare behaviors in high-risk third trimester pregnancies. (Master of Science in Nursing), University of Toledo, USA.

Callister, L. C., \& Khalaf, I. (2010). Spirituality in childbearing women. Journal of Perinatal Education, 19(2), 16-24. Retrieved from http://search.ebscohost.com/login.aspx?direct=true \&db=rzh\&AN=2010708099\&site =ehost-live \&scope=site. doi:10.1624/105812410x495514

Clarry, L., \& Carson, J. (2018). Development and pilot of a positive measure of maternal mental health: The C-MEWS. J Journal of Health Visiting, 6(8), 394-403.

Crowther, S. (2017). Birth as sacred celebration. In S. Crowther \& J. Hall (Eds.), Spirituality and Childbirth: Meaning and Care at the Start of Life (pp. 13-29): Taylor \& Francis.

Crowther, S., Smythe, L., \& Spence, D. (2014). Mood and birth experience. Women and birth : journal of the Australian College of Midwives, 27(1), 21-25. Retrieved from 
http://aut.summon.serialssolutions.com/2.0.0/link/0/eLvHCXMwVZ07DgIxEEMjXAm QoOYCK-

Uzn6RGrDjAXiCZjEvuX5KCAi5gd5afG4dwr0xFpsrg3BTZK1brT92YBkea9rfn_qT5fgknf1 DsT-

Px2v7ngFsLq1s2pdZ6qjN2A08QLb0KVofgHsmwUSesagm1EnECzwmiaBksKZbOC-e9g-

PwidG

https://www.womenandbirth.org/article/S1871-5192(13)00035-8/pdf.

doi:10.1016/j.wombi.2013.02.004

Crowther, S., Smythe, L., \& Spence, D. (2015). Kairos time at the moment of birth Midwifery, 31, 451-457. Retrieved from

http://www.sciencedirect.com/science/article/pii/S0266613814002605.

doi:http://dx.doi.org/10.1016/j.midw.2014.11.005

Davis-Floyd, R. (2017). Ways of Knowing about Birth: Mothers, Midwives, Medicine, and Birth Activism.

Delaporte, M., \& Martin, M. (2018). Sacred inception : reclaiming the spirituality of birth in the modern world. Lanham: Lexington Books.

Dietsch, E., Martin, T., Shackleton, P., Davies, C., McLeod, M., Alston, M. J. W., \& Birth. (2011). Australian Aboriginal kinship: a means to enhance maternal well-being. 24(2), 58-64.

Dixon-Woods, M., Cavers, D., Agarwal, S., Annandale, E., Arthur, A., Harvey, J., . . . Smith, L. (2006). Conducting a critical interpretive synthesis of the literature on access to healthcare by vulnerable groups. J BMC medical research methodology, 6(1), 35.

Farry, A., \& Crowther, S. (2014). Cultural safety in New Zealand midwifery practice. Part 2. Pract Midwife, 17(7), 30-33. Retrieved from https://www.ncbi.nlm.nih.gov/pubmed/25109074.

Hall, J. (2016). Spirituality and Midwifery. In M. de Souza, J. Bone, \& J. Watson (Eds.), 2016. Spirituality across disciolines: Research and Practice (pp. 217-228). Switzerland: Springer.

Hanely, J., \& Brown, A. (2014). Cultural variations in interpretation of postnatal illness: Jinn possession amongst Muslim communities. Community Mental Health Journal, 50(3), 348-353. Retrieved from http://europepmc.org/abstract/MED/23955293

https://doi.org/10.1007/s10597-013-9640-4. doi:10.1007/s10597-013-9640-4

Hanely, J., \& Brown, A. J. C. m. h. j. (2014). Cultural variations in interpretation of postnatal illness: jinn possession amongst Muslim communities. 50(3), 348-353.

Howard, L. M., Megnin-Viggars, O., Symington, I., \& Pilling, S. (2014). Antenatal and postnatal mental health: summary of updated NICE guidance. British Medical Journal (Clinical Research Ed.), 349.

Jesse, D. E., \& Reed, P. G. (2004). Effects of spirituality and psychosocial well-being on health risk behaviors in Appalachian pregnant women. J Journal of Obstetric, Gynecologic, Neonatal Nursing, 33(6), 739-747. 
Jones, S., Cymru, M., \& O'Leary, S. (2018). From bumps to babies: perinatal mental health care in Wales. Wales: NSPCC

Kirkup, B. (2015). The report of the Morecambe Bay investigation. The Stationery Office, London.

Kitzinger, S. (2012). Rediscovering the social model of childbirth. Birth, 39(4), 301-304.

Retrieved from http://www.scopus.com/inward/record.url?eid=2-s2.0-

84869851712\&partnerID=40\&md5=e77173f6d4ed459986d89f99d4fcc29d. doi:10.1111/birt.12005

Lahood, G. (2007). Rumour of angels and heavenly midwives: Anthropology of transpersonal events and childbirth. Women and Birth, 20(1), 3-10. Retrieved from http://www.scopus.com/inward/record.url?eid=2-s2.033847330323\&partnerID=40\&md5=ca025d36a469d53ab76efd6c058c56a6.

Lemay, C., \& Hastie, C. J. (2017). Holding sacred space in labour and birth. In S. Crowther \& J. Hall (Eds.), Spirituality Childbirth: Meaning Care at the Start of Life.

Lundgren, I. (2002). Releasing and relieving encounters. Experiences of pregnancy and childbirth. . (PhD), Universitatis Upsaliensis. , Uppsala, Sweden.

Maternal Mental Health Alliance. (2016). Everyone's Business Campaign External Evaluation Report. Gillian Granville Associates \& WSA Community Consultants

MBRRACE-UK. (2015). Saving Lives, Improving Mothers' Care - Surveillance of maternal deaths in the UK 2011-13 and lessons learned to inform maternity care from the UK and Ireland. Confidential Enquiries into Maternal Deaths and Morbidity 2009-13. University of Oxford: Oxford

Mitchell, M. (2012). Narrative accounts of women who use complementary and alternative medicine in pregnancy:'Forewarned, forearmed and relaxed'. (PhD), University of the West of England,

Moher, D., Liberati, A., Tetzlaff, J., \& Altman, D. (2009). Preferred reporting items for systematic reviews and meta-analyses: the PRISMA statement. J Annals of internal medicine, 151(4), 264-269.

Moloney, S., \& Gair, S. (2015). Empathy and spiritual care in midwifery practice: Contributing to women's enhanced birth experiences. Women Birth, 28(4), 323-328. doi:10.1016/j.wombi.2015.04.009

NICE. (2014). Antenatal and postnatal mental health: clinical management and service guidance. CG192: . UK: National Institute for Health and Care Excellence

NMC. (2010). Standards for competence for registered midwives. London

Noblit, G. W., Hare, R. D., \& Hare, R. (1988). Meta-ethnography: Synthesizing qualitative studies (Vol. 11): sage.

Oladapo, OT, Tunçalp, Ö, Bonet, M, Lawrie, TA, Portela, A, Downe, S, Gülmezoglu, AM. WHO model of intrapartum care for a positive childbirth experience: transforming care of women and babies for improved health and wellbeing. BJOG 2018; 125: 918-922.

Orem, D. (2001). Nursing: Concepts of Practice, 6th edn. St Louis: Mosby. In: Inc. 
Parratt, J., \& Fahy, K. M. (2008). Including the nonrational is sensible midwifery. Women and Birth, 21(1), 37-42. Retrieved from http://www.scopus.com/inward/record.url?eid=2-s2.039649121481\&partnerID=40\&md5=079915f17b458036603efef9c945f03c.

Pembroke, N. F., \& Pembroke, J. J. (2008). The spirituality of presence in midwifery care. Midwifery, 24(3), 321-327. Retrieved from http://www.scopus.com/inward/record.url?eid=2-s2.048349119555\&partnerID=40\&md5=063e4ceecb1dbdc626bde2785ad328a4.

RCM. (2015). Caring for Women with Mental Health Problems Standards and Competency Framework for Specialist Maternal Mental Health midwives. London: Royal Collge of Midwives

Ross-Davie, M., Elliott, S., Sarkar, A., \& Green, L. J. B. J. o. M. (2006). A public health role in perinatal mental health: are midwives ready? British Journal of Midwifery, 14(6), 330-334.

Takehara K, Noguchi M \& Shimane T, 2009, The positive psychological impact of rich childbirth experiences on child-rearing, Japanese Journal of Public Health, vol. 56, no. 5, pp. 312-321.

Whittemore, R., \& Knafl, K. (2005). The integrative review: updated methodology. J Journal of advanced nursing, 52(5), 546-553.

WHO. ((undated)). Maternal mental health. https://www.who.int/mental_health/maternalchild/maternal_mental_health/en/:WHO Retrieved from https://www.who.int/mental_health/maternal-child/maternal_mental_health/en/

Wojtkowiak, J., \& Crowther, S. (2018). An existential and spiritual discussion about childbirth: Contrasting spirituality at the beginning and end of life. Spirituality in Clinical Practice, 5(4), 261-272. doi:10.1037/scp0000188 
Table 1: Summary of descriptive characteristics of the 6 included studies

\begin{tabular}{|c|c|c|c|c|c|c|}
\hline $\begin{array}{l}\text { Study } \\
\text { no. }\end{array}$ & $\begin{array}{l}\text { Data } \\
\text { base * }\end{array}$ & Full reference & Type of report accessed & Aim or/and objectives & Setting & Participants \\
\hline 1 & $\begin{array}{l}\text { Open } \\
\text { Thesis }\end{array}$ & $\begin{array}{l}\text { Brinkley, R.L. (2004) The } \\
\text { correlation between perceived } \\
\text { stress and health promoting self- } \\
\text { care behaviours in high-risk third } \\
\text { trimester pregnancies } \\
\text { Thesis }\end{array}$ & $\begin{array}{l}\text { Whole thesis accessed } \\
\text { https://pdfs.semanticscholar.org/e } \\
\text { ce5/8ff23b85a99983579d47ab9cf9 } \\
\underline{\text { 5fc020130b.pdf }}\end{array}$ & $\begin{array}{l}\text { To explore the impact of maternal } \\
\text { perceived stress in high-risk } \\
\text { pregnancy on participation in health } \\
\text { promoting self-care }\end{array}$ & USA & 69 women \\
\hline 2 & CINAHL & $\begin{array}{l}\text { Hanely, J., \& Brown, A. (2014). } \\
\text { Cultural variations in } \\
\text { interpretation of postnatal } \\
\text { illness: Jinn possession amongst } \\
\text { Muslim communities. } \\
\text { Community Mental Health } \\
\text { Journal, 50(3), 348-353. }\end{array}$ & $\begin{array}{l}\text { Full article doi:10.1007/s10597- } \\
\underline{013-9640-4}\end{array}$ & $\begin{array}{l}\text { Explore maternal experience of Jinn } \\
\text { possession and draw parallels with } \\
\text { Western interpretations of postnatal } \\
\text { illness. }\end{array}$ & Arabian Gulf state & 10 women \\
\hline 3 & $\begin{array}{l}\text { Open } \\
\text { Thesis }\end{array}$ & $\begin{array}{l}\text { Lundgren, I. (2002) Releasing and } \\
\text { relieving encounters: } \\
\text { Experiences of pregnancy and } \\
\text { childbirth } \\
\text { Thesis }\end{array}$ & $\begin{array}{l}\text { Whole thesis accessed } \\
\text { https://www.diva- } \\
\text { portal.org/smash/get/diva2:16165 } \\
\text { 4/FULLTEXT01.pdf }\end{array}$ & $\begin{array}{l}\text { Describe and analyse these childbirth } \\
\text { experiences from the women's } \\
\text { perspective as well as the encounter } \\
\text { between the woman and the } \\
\text { midwife, and the possibility that a } \\
\text { birth plan might improve women's } \\
\text { experience of childbirth. }\end{array}$ & Sweden & $\begin{array}{l}581 \text { women } \\
9 \text { midwives }\end{array}$ \\
\hline 4 & $\begin{array}{l}\text { Open } \\
\text { Thesis }\end{array}$ & $\begin{array}{l}\text { Mitchell, M. (2012) } \\
\text { Narrative accounts of women } \\
\text { who use complementary and } \\
\text { alternative medicine in } \\
\text { pregnancy: 'Forewarned, } \\
\text { forearmed and relaxed'. Thesis }\end{array}$ & $\begin{array}{l}\text { Whole thesis accessed } \\
\text { http://eprints.uwe.ac.uk/18485/1/ } \\
\text { Narrative\%20Accounts\%20of\%20W } \\
\text { omen\%20who\%20use\%20Comple } \\
\text { mentary\%20and\%20Alternative\%2 } \\
\text { OMedicine\%20in\%20pregnancy.pdf }\end{array}$ & $\begin{array}{l}\text { To explore the experiences of } \\
\text { women who use CAM during } \\
\text { pregnancy and } \\
\text { childbirth in an attempt to } \\
\text { understand the meaning they ascribe } \\
\text { to CAM use. }\end{array}$ & UK & 14 women \\
\hline 5 & CINAHL & $\begin{array}{l}\text { Bennington, L. (2010). The } \\
\text { relationship among maternal } \\
\text { infant bonding, spirituality, and } \\
\text { maternal perception of } \\
\text { childbirth experience. Thesis }\end{array}$ & $\begin{array}{l}\text { Whole thesis accessed } \\
\text { https://scholarscompass.vcu.edu/c } \\
\text { gi/viewcontent.cgi?referer=https:// } \\
\text { scholar.google.co.uk/\&httpsredir=1 } \\
\text { \&article=3241\&context=etd }\end{array}$ & $\begin{array}{l}3 \text { objectives a) Examine the } \\
\text { relationship between a woman's } \\
\text { perceived birth experience and } \\
\text { maternal-infant bonding; (b) } \\
\text { Examine the relationship between } \\
\text { spirituality and maternal-infant }\end{array}$ & $\begin{array}{l}\text { Internet survey } \\
\text { Global }\end{array}$ & 402 women \\
\hline
\end{tabular}


Data extraction and synthesis of themes illustrated via six tables $7^{\text {th }}$ Dec updated

\begin{tabular}{|c|c|c|c|c|c|c|}
\hline & & & & $\begin{array}{l}\text { bonding; (c) Examine the relationship } \\
\text { between perceived birth experience, } \\
\text { spirituality, and maternal-infant } \\
\text { bonding. }\end{array}$ & & \\
\hline 6 & $\begin{array}{l}\text { Science } \\
\text { Direct }\end{array}$ & $\begin{array}{l}\text { Dietsch, E., Martin, T., } \\
\text { Shackleton, P., Davies, C., } \\
\text { McLeod, M., Alston, M. J. (2011). } \\
\text { Australian Aboriginal kinship: a } \\
\text { means to enhance maternal } \\
\text { well-being. Women \& Birth. } \\
\text { 24(2), 58-64. Australian } \\
\text { Aboriginal kinship: A means to } \\
\text { enhance maternal well-being }\end{array}$ & $\begin{array}{l}\text { Full article } \\
\text { https://doi.org/10.1016/i.wombi.2 } \\
\underline{\underline{010.06 .003}}\end{array}$ & $\begin{array}{l}\text { Explore the multi-faceted dichotomy } \\
\text { related to the mental health of } \\
\text { postnatal Aboriginal women in } \\
\text { relation to kinship. }\end{array}$ & Rural Australia & $\begin{array}{l}3 \text { Aboriginal } \\
\text { women } \\
1 \text { partner }\end{array}$ \\
\hline
\end{tabular}

*Some papers were located in more than one database - this indicates the database where the study was first located 


\section{Table 2: Methodological characteristics of included studies}

\begin{tabular}{|c|c|c|c|c|c|}
\hline $\begin{array}{l}\text { Study } \\
\text { No. }\end{array}$ & STUDY & $\begin{array}{l}\text { STUDY DESIGN/ } \\
\text { METHODOLOGY }\end{array}$ & $\begin{array}{l}\text { SAMPLING } \\
\text { METHODS }\end{array}$ & DATA COLLECTION & DATA ANALYSIS PROCESSES \\
\hline 1 & Brinkley (2004) & $\begin{array}{l}\text { Descriptive } \\
\text { correlational }\end{array}$ & $\begin{array}{l}\text { Secondary } \\
\text { analysis of } \\
\text { de-identified } \\
\text { data from a } \\
\text { larger study }\end{array}$ & $\begin{array}{l}\text { Single interviews with } \\
\text { pregnant women. }\end{array}$ & $\begin{array}{l}\text { Secondary qualitative analysis which allowed for examination } \\
\text { of data from questions not previously posed. Analyzed data } \\
\text { from PSS (measures the degree an individual perceives his or } \\
\text { her life situations as stressful) and HPLP II (assesses holistic } \\
\text { self-care behaviours including spiritual growth \& stress } \\
\text { management). }\end{array}$ \\
\hline 2 & $\begin{array}{l}\text { Hanely \& Brown } \\
\text { (2014). }\end{array}$ & $\begin{array}{l}\text { Qualitative. } \\
\text { Exploratory study. }\end{array}$ & $\begin{array}{l}\text { Purposive } \\
\text { sampling }\end{array}$ & $\begin{array}{l}\text { Individual interviews } \\
\text { conducted in Arabic }\end{array}$ & $\begin{array}{l}\text { Inductive thematic descriptive analysis informed by } \\
\text { Sandelowski. Two independent coders } \\
\text { with } 90 \% \text { agreement of final themes. }\end{array}$ \\
\hline 3 & $\begin{array}{l}\text { Lundgren } \\
(2002)^{*}\end{array}$ & $\begin{array}{l}\text { Mixed methods: } \\
\text { hermeneutic } \\
\text { phenomenology \& } \\
\text { questionnaires }\end{array}$ & $\begin{array}{l}\text { Purposive } \\
\text { sampling from } 7 \\
\text { maternity units } \\
\text { using } \\
\text { consecutive } \\
\text { recruiting } \\
\text { strategies }\end{array}$ & $\begin{array}{l}39 \text { women interviewed } \\
\text { before and after birth } \\
542 \text { women questionnaires } \\
9 \text { midwives' interviews }\end{array}$ & $\begin{array}{l}\text { Interpretive hermeneutic analysis } \\
\text { and statistical analysis using SPSS cross-tabulation program was } \\
\text { used for the calculations of differences (chi-squared) and a p- } \\
\text { value of less than } 0.05 \text { was considered significant. In the result } \\
\text { the extreme answers, i.e. } 1+2 \text { (almost or totally disagree) and } \\
5+6 \text { (almost or totally agree) are presented. All scores (1-6) } \\
\text { were used in the calculation of Chi-Square. Both studies lead to } \\
\text { synthesised themes }\end{array}$ \\
\hline 4 & Mitchell (2012) & Narrative inquiry & $\begin{array}{l}\text { Purposive } \\
\text { sampling and } \\
\text { snowballing }\end{array}$ & $\begin{array}{l}\text { Interviews 1-2 hours (each } \\
\text { women 2-3 times) }\end{array}$ & $\begin{array}{l}\text { Narrative analysis employing a four stage approach leading to } \\
\text { themes }\end{array}$ \\
\hline 5 & $\begin{array}{l}\text { Bennington } \\
(2010) \text {. }\end{array}$ & $\begin{array}{l}\text { Quantitative. } \\
\text { retrospective, } \\
\text { cross-sectional, } \\
\text { correlational and } \\
\text { descriptive }\end{array}$ & $\begin{array}{l}\text { Convenience } \\
\text { sample }\end{array}$ & $\begin{array}{l}\text { Women received survey } \\
\text { (Survey Monkey) } \\
\text { questionnaires via website. } \\
\text { Instruments used: (a) } \\
\text { Measurement of Spirituality } \\
\text { (Bennington, 2003), (b) } \\
\text { Perception of Childbirth } \\
\text { Experience scale (Marut \& } \\
\text { Mercer, 1979), (c) Maternal } \\
\text { Attachment Inventory } \\
\text { (Müller, 1994) }\end{array}$ & $\begin{array}{l}\text { Statistical analysis included both multivariate and correlation } \\
\text { analysis using Pearson's r or Spearman's rho and multiple } \\
\text { regression analysis. The variables investigated in this research } \\
\text { were: } \\
\text { (a) Spirituality-independent variable } \\
\text { (b) Women's Perceived Birth Experience-independent } \\
\text { variable } \\
\text { (c) Maternal Infant Bonding-dependent variable. }\end{array}$ \\
\hline
\end{tabular}




\begin{tabular}{|l|l|l|l|l|}
\hline 6 & $\begin{array}{l}\text { Dietsch, et al } \\
\text { (2011). }\end{array}$ & $\begin{array}{l}\text { Qualitative } \\
\text { Descriptive }\end{array}$ & $\begin{array}{l}\text { In-depth interviews. } \\
\text { Published paper reports on } \\
\text { a sub-set of interview data. } \\
\text { The larger study explored } 42 \\
\text { women's experience of } \\
\text { having to leave their rural } \\
\text { communities to birth. }\end{array}$ & $\begin{array}{l}\text { Data analysis was thematic and conducted by individual } \\
\text { research team members and then by research team pairs. Only } \\
\text { these } \\
\text { to identified by paired-consensus were submitted } \\
\text { inclusion. }\end{array}$ \\
\hline
\end{tabular}

*Note: Lundgren, I (2002) is a thesis by publication reporting on five published papers. This review has examined these papers and data from three of them has been extracted and indicated in the findings below. Lundgren, I. and Dahlberg K (2002) Midwives' experience of the encounter with women and their pain during childbirth. Midwifery, 2, 155-164; Lundgren I, Dahlberg K (1998) Women's experience of pain during childbirth. Midwifery, 14, 105-110 and Lundgren, I., Wahlberg, V. 1999. The experience of pregnancy: a hermeneutical/ phenomenological study. The Journal of Perinatal Education, 3, 12-20.

Table 3: Themes represented across the 7 included studies

\begin{tabular}{|c|c|c|c|c|c|c|}
\hline SYNTHESISED THEMES & STUDY 1 & STUDY 2 & STUDY 3 & STUDY 4 & STUDY 5 & STUDY 6 \\
\hline Relationships and kinship matter (table 4a) & $X$ & $X$ & $X$ & $\mathrm{X}$ & $\mathrm{X}$ & $\mathrm{X}$ \\
\hline Significance of childbirth \& spiritual experiences (table $4 b$ ) & & $\mathrm{X}$ & $\mathrm{X}$ & $\mathrm{X}$ & $\mathrm{X}$ & $\mathrm{X}$ \\
\hline Honouring spiritual growth and wellbeing (Table 4c) & $\mathrm{X}$ & & $\mathrm{X}$ & $\mathrm{X}$ & & \\
\hline Physical manifestations and embodiment (Table 4d) & $\mathrm{X}$ & $\mathrm{X}$ & & $\mathrm{X}$ & & \\
\hline
\end{tabular}


Table 4a. Synthesised theme: Relationships and kinship matter

\begin{tabular}{|c|c|c|c|}
\hline $\begin{array}{l}\text { STUDY } \\
\text { NO. }\end{array}$ & $\begin{array}{l}\text { STUDY AUTHOR } \\
\text { THEMES/ } \\
\text { INTERPRETATIONS }\end{array}$ & REVIEWERS INTERPRETATIONS & SUPPORTING DATA \\
\hline 1 & $\begin{array}{l}\text { Interpersonal } \\
\text { relationships are } \\
\text { disrupted and stress } \\
\text { increases when a } \\
\text { woman is exhausted } \\
\text { and has no adequate } \\
\text { opportunity to rest. } \\
\text { Adequate rest is } \\
\text { correlated with } \\
\text { positive relationships }\end{array}$ & $\begin{array}{l}\text { Interpersonal relationships } \\
\text { matter. }\end{array}$ & $\begin{array}{l}\text { Higher levels of stress reported when inadequate rest periods. Need for maintaining } \\
\text { balance specifically with sleep deprivation correlated with increasing parity. Lack of rest } \\
\text { and sleep correlated with poorer interpersonal relationships }(N=68, r=.300, p=.013) \text { and } \\
\text { less spiritual growth ( } N=68, r=.249, p=.04) \text { and stress management }(N=68, r=.280 \text {, } \\
p=.021) \text {. Proper rest positively correlated with interpersonal relations and stress } \\
\text { management ( } p .41) \text {. }\end{array}$ \\
\hline 2 & $\begin{array}{ll}\text { - } & \text { shared } \\
\text { knowledge of } \\
\text { Jinn possession, } \\
\text { - } & \text { symptoms of } \\
\text { possession, } \\
\text { - } \\
\text { risk factors for } \\
\text { possession } \\
\text { preventing and } \\
\text { treating Jinn } \\
\text { possession. }\end{array}$ & $\begin{array}{l}\text { Social support is crucial. } \\
\text { Risk factors for jinn possession } \\
\text { are being alone, isolated. } \\
\text { Symptoms of possession include } \\
\text { being unable to connect with } \\
\text { others. Loss of appetite, losing } \\
\text { weight and tiredness are } \\
\text { common physical effects of Jinn } \\
\text { possession, perhaps mirroring } \\
\text { post natal depression symptoms } \\
\text { in western cultures. }\end{array}$ & $\begin{array}{l}\text { I am lonely because I love my husband very much but he is always away at sea and I don't } \\
\text { see him very often. [Woman participant] } \\
\text { I cannot rely on my family to help me as they are wrapped up in themselves. [Woman } \\
\text { participant] } \\
\text { I have no energy and I cannot look after my baby [woman participant] } \\
\text { When the baby was born I did not want to see her...I cried and cried. [Woman participant] }\end{array}$ \\
\hline 3 & $\begin{array}{l}\text { Releasing and } \\
\text { relieving } \\
\text { encounters } \\
0 \quad \text { Anchored } \\
\quad \text { companion }\end{array}$ & $\begin{array}{l}\text { The way health care providers } \\
\text { practice around childbirth is } \\
\text { significant and affects the } \\
\text { woman's experience. }\end{array}$ & $\begin{array}{l}\text { To use the woman's capacity. What they think about. It takes different time for different } \\
\text { women, but I think most women can do this if you give them enough support. And } \\
\text { afterwards they can say: 'I can do this. Good Lord, what I can do. My body is capable.' You } \\
\text { get so aware of your body's capability. I think this is good for the women. (Lundgren 2002, } \\
\text { 159) }\end{array}$ \\
\hline
\end{tabular}




\begin{tabular}{|c|c|c|c|}
\hline & $\begin{array}{l}\text { a) Be seen as } \\
\text { individual } \\
\text { b) Have trusting } \\
\text { relationship } \\
\text { c) Relationship is } \\
\text { more important } \\
\text { than a birth plan }\end{array}$ & $\begin{array}{l}\text { Relationships based on trust and } \\
\text { being there fully facilitates } \\
\text { positive childbirth experiences. }\end{array}$ & \\
\hline 4 & $\begin{array}{l}\text { Assistance and help } \\
\text { from CAM } \\
\text { practitioners and } \\
\text { midwives who share } \\
\text { that holistic } \\
\text { perspective helps } \\
\text { support wellbeing. } \\
\text { Kindness, caring and } \\
\text { empathy in which } \\
\text { woman's experiences } \\
\text { are understood and } \\
\text { valued are beneficial. }\end{array}$ & $\begin{array}{l}\text { Getting holistic trusting support } \\
\text { from others is important and } \\
\text { helps sustain and nurture } \\
\text { emotional wellbeing. }\end{array}$ & $\begin{array}{l}\text { The osteopath I saw was very reassuring, she was absolutely lovely, she was so lovely in } \\
\text { fact I think I burst into tears the first time I went to see her afterwards. I had so many } \\
\text { problems with my back and it was really getting me down I mean I cried when I left her } \\
\text { because it was such a sense of relief that she understood that I was in pain and that she } \\
\text { was going to help me the way I wanted } \\
\text { to be helped'. (Rose, Ist interview) } \\
\text { It was brilliant, to know that she was a midwife as well and to know that she sees it from } \\
\text { that angle. It definitely sealed, confirmed my trust in it and it was nice. It made her feel } \\
\text { very connected with my pregnancy and it was nice you know. There was the kind of } \\
\text { compassion about her. I don't know, there was just something very nice about the way } \\
\text { she would kind of feel the position of the baby and just that kind of confidence in her } \\
\text { touch around the baby and the abdomen. It was really nice and very reassuring [Rose, } 2^{\text {nd }} \\
\text { Interview] } \\
\text { 'I saw her when I had a foot injury, the bereavement of my father and then being } \\
\text { pregnant and then birth, so it has felt like quite a journey and we just seemed to really } \\
\text { click. I felt nurtured, very open and very warm person and someone I felt I could trust. I } \\
\text { felt like she knew me as a person. I felt really understood and she had seen me at times of } \\
\text { real pain. I also feel like she had seen quite a change in me from when I first started } \\
\text { seeing her right the way though in terms of being aware of myself and putting my needs } \\
\text { first sometimes and how I am as a person becoming a lot more assertive, especially in } \\
\text { pregnancy. I felt a definite connection in terms of understanding me as a person and my } \\
\text { emotions and feelings'. (Rachel, 2nd interview)p105 } \\
\text { 'because I had such a good birth experience, I felt because I had been able to give birth to } \\
\text { him that well that I am a good mother in some way. That I am this earth mother and it is } \\
\text { in my blood. I felt instantly connected with him. Perhaps also because he just fell out and } \\
\text { he didn't cause me so much pain. Perhaps I am not having any grudge towards him. I } \\
\text { don't think gosh I wish I hadn't had you or perhaps I would have done it differently and I }\end{array}$ \\
\hline
\end{tabular}




\begin{tabular}{|c|c|c|c|}
\hline & & & $\begin{array}{l}\text { don't have that feeling. It was perfect in every way and I definitely think I have a much } \\
\text { better relationship with him because it was so nice'. (Alexandra } 2 \text { nd interview) p125 }\end{array}$ \\
\hline 5 & Bonding & $\begin{array}{l}\text { Perceived birth experience had } \\
\text { strong correlation to maternal } \\
\text { infant bonding and was found to } \\
\text { have a stronger influence on } \\
\text { bonding than spirituality. (NB. } \\
\text { Care needs to be taken not to } \\
\text { conflate bonding with } \\
\text { attachment, see discussion) }\end{array}$ & $\begin{array}{l}\text { the strongest influence on maternal infant bonding (MFA) } \\
\text { in the regression analysis was a woman's perception of her birth experience (POBS) as } \\
\text { revealed by an } R \text {-squared of } 0.055, p<0.01 \text {, which represents } 5.5 \% \text { of the proportion of } \\
\text { variation in maternal infant bonding. Furthermore, the correlation analysis between } \\
\text { POBS and MFA demonstrated a correlation of } 0.234, p<0.01 \text {. ' } p 83 \\
\text { 'spirituality had an } R \text {-squared of } 0.014, p<0.05 \text { which means } 1.4 \% \text { of the proportion of } \\
\text { variation in maternal infant bonding is explained by this variable. The correlation } \\
\text { between MFA and Spirituality was } 0.162, p<0.01 \text {. The moderately high mean of the } \\
\text { spirituality survey for the respondents was } 49.61 \text { and SD of } 7.85 \text {. Although spirituality } \\
\text { was noted to be of significance it was a weaker predictor of maternal infant bonding than } \\
\text { POBS.'p84 }\end{array}$ \\
\hline 6 & $\begin{array}{ll}\text { Racial abuse and } \\
\text { bullying } \\
\text { Emotional } \\
\text { stressors } \\
\text { including } \\
\text { feelings of } \\
\text { intense } \\
\text { loneliness, } \\
\text { incarceration } \\
\text { and abject fear } \\
\text { which were } \\
\text { exacerbated by } \\
\text { the participants' } \\
\text { sense of solation } \\
\text { Protective } \\
\text { impact of strong } \\
\text { kinship }\end{array}$ & $\begin{array}{l}\text { Kinship and quality of } \\
\text { relationships relate to perinatal } \\
\text { mental wellbeing. } \\
\text { Culturally insensitive health care } \\
\text { providers can cause spiritual } \\
\text { harm to childbearing women that } \\
\text { may contribute to postnatal } \\
\text { mood disorders. }\end{array}$ & $\begin{array}{l}\text { Well, I knew I was going to [centralised hospital], and once } \\
\text { I got there I just cried, because I got really depressed } \\
\text { (Kerry). } \\
\text { She left here bright and happy and looking forward to the future, and came back like an } \\
\text { old woman, like a broken woman. That's what she was like. I really think it scarred her. I } \\
\text { think it's really brutal, it's shocking. It's disgusting, the way they were treating her. } \\
\text { [Husband - Henry] }\end{array}$ \\
\hline
\end{tabular}




\section{Table 4b. Synthesised theme: Significance of childbirth and spiritual experiences}

\begin{tabular}{|c|c|c|c|}
\hline $\begin{array}{l}\text { STUDY } \\
\text { No. }\end{array}$ & $\begin{array}{l}\text { STUDY AUTHOR } \\
\text { THEMES/ } \\
\text { INTERPRETATIONS }\end{array}$ & REVIEWERS' INTERPRETATIONS & SUPPORTING DATA \\
\hline 2 & $\begin{array}{l}\text { - } \quad \text { risk factors for } \\
\text { possession }\end{array}$ & $\begin{array}{l}\text { Cultural and spiritual practices } \\
\text { and cosmologies are significant } \\
\text { in and around childbirth. This } \\
\text { could in turn negatively } \\
\text { influence postnatal moods. }\end{array}$ & $\begin{array}{l}\text { Perhaps it was your fault that you have the Jinn. Perhaps you walked on the land of the } \\
\text { Jinn or drank from their well. [Women] } \\
\text { As for any postnatal woman I was kept in the } \\
\text { dark behind the curtain and I didn't like it. I got some relief } \\
\text { when I pulled up the curtains and got some light. I got sick from the moment I give birth. } \\
\text { I couldn't act like a postnatal woman. [Rural woman with Wuqabi] }\end{array}$ \\
\hline 3 & $\begin{array}{l}\text { - } \quad \text { Meeting one's life } \\
\text { situation } \\
\text { - Meeting something } \\
\text { inevitable } \\
\text { - } \quad \text { Preparing for the } \\
\text { unknown } \\
\text { Be supported and } \\
\text { guided on one's } \\
\text { own terms } \\
\text { Stillness and } \\
\text { presence (being in } \\
\text { the moment) }\end{array}$ & $\begin{array}{l}\text { Childbirth is an experience of } \\
\text { unpredictability and transitions } \\
\text { that can be challenging. The } \\
\text { releasing and relieving } \\
\text { encounters (overarching themes } \\
\text { in this work) gesture transitions. }\end{array}$ & $\begin{array}{l}\text { You see things totally different afterwards, you have another way of understanding.., } \\
\text { you accept things differently, you become stronger, you can cope with things better } \\
\text { than before.., before petty details could ruin life, and now you just shake it off your } \\
\text { shoulders, you don't become another personality..., but you mature and become a } \\
\text { stronger personality, when you've had a baby and have gone through that pain. I think } \\
\text { that is the purpose of it, what the meaning of life is. I think it is to protect our children, } \\
\text { to be stronger, a way of managing everyday life and become stronger, and that it is a } \\
\text { life from your own flesh and blood and that too helps you to go through the delivery. } \\
\text { (Lundgren 1998, 108) } \\
\text { For the woman a releasing and relieving encounter constitutes an encounter with } \\
\text { herself as well as with the midwife. A releasing and relieving encounter also implies } \\
\text { stillness as well as change. Stillness is expressed as being in the moment; exemplified as } \\
\text { presence and being one's body. Change is expressed as transition; to the unknown and } \\
\text { to motherhood. (p36) }\end{array}$ \\
\hline 4 & $\begin{array}{l}\text { Values and beliefs with } \\
\text { dominant childbirth } \\
\text { care may be conflicting } \\
\text { with individual woman } \\
\text { who then seek holistic } \\
\text { support from CAM } \\
\text { practitioners who are }\end{array}$ & $\begin{array}{l}\text { Congruence with one's belief's } \\
\text { and values about childbirth are } \\
\text { important because childbirth } \\
\text { and spiritual experiences are } \\
\text { significant. Therefore, need to } \\
\text { find care providers who } \\
\text { resonate with one's own }\end{array}$ & $\begin{array}{l}\text { 'the horror stories, managed labour, slicing and dicing. If you're in labour, if you don't } \\
\text { give birth in } 7 \text { hours you will get a section and that you are forced into routes that you } \\
\text { don't want to. Everybody I knew ended up with a section, absolutely everybody. I don't } \\
\text { know of one person that has given birth naturally in the ...(local trust). (Stephanie, 2nd } \\
\text { interview) } \\
\text { Alexandra practised hypnobirthing techniques in }\end{array}$ \\
\hline
\end{tabular}




\begin{tabular}{|c|c|c|c|}
\hline & $\begin{array}{l}\text { congruent with their } \\
\text { belief beliefs about } \\
\text { childbirth. } \\
\text { Uncertainty has a } \\
\text { profound effect on } \\
\text { women and can lead to } \\
\text { fear and anxiety } \\
\text { impacting their } \\
\text { confidence initiating } \\
\text { support seeking beyond } \\
\text { state health care } \\
\text { system. }\end{array}$ & $\begin{array}{l}\text { orientation lest one is left } \\
\text { feeling vulnerable and bereft of } \\
\text { the type of support and } \\
\text { guidance needed. The right } \\
\text { support and guidance can } \\
\text { mitigate the unpredictability of } \\
\text { childbirth and provide } \\
\text { reassurance and the experience } \\
\text { helping to provide peace of } \\
\text { mind. } \\
\text { Perhaps lack of congruence } \\
\text { between beliefs/values and } \\
\text { dealing with high levels of } \\
\text { unpredictability affects } \\
\text { emotional wellbeing and may } \\
\text { lead to post-natal mood } \\
\text { disorders. }\end{array}$ & $\begin{array}{l}\text { labour and was convinced this contributed to her positive birth experience: } \\
\text { 'It was so easy during labour. It was a bit like fleeing into that other world which was full } \\
\text { of calm and serenity. I just didn't have to think about the labour at all, about the pain, it } \\
\text { was just not there really. I was so calm'. (Alexandra, 1st interview) } \\
\text { was so clear what I wanted but also because you have no idea what is going to happen. } \\
\text { Your body is about to go through something and you have no idea can it? will it?, will it } \\
\text { go well?, will I be one of those lucky women who just breathe this baby out?, will I have } \\
\text { some horrendous hospital experience?, will it be traumatic?, Will I be the same?, will I } \\
\text { recover from this? I mean you go through every question in the world'. (Riley, 1st } \\
\text { interview) }\end{array}$ \\
\hline 5 & 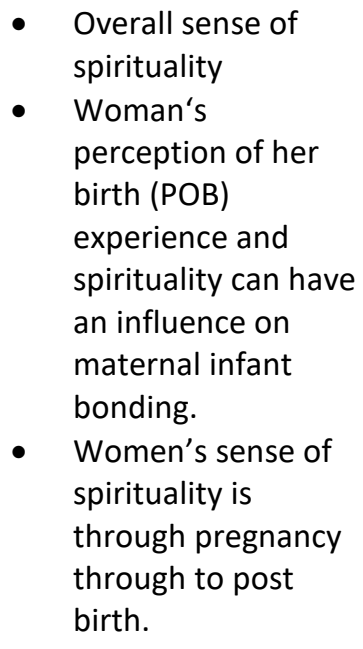 & $\begin{array}{l}\text { Spirituality is significant in } \\
\text { childbirth year. Spirituality and } \\
\text { POB experiences affect the } \\
\text { relationship between mother } \\
\text { and infant. }\end{array}$ & $\begin{array}{l}\text { The mean score for spirituality was } 49.61, \text { SD of } 7.85 \text { (possible range of } 12-60 \text { ) } \\
\text { suggesting an overall sense of spirituality as previously defined for the respondents. } \\
\text { Spirituality has some influence on MFA at a signficance value of } 0.05 \text { ( } p<0.05 \text { ). } \\
\text { Spirituality as being of equivocal significant at a level of } 0.05 \text { when examined } \\
\text { individually as a predictor of MFA and when used in conjunction with POBS } \\
\text { demonstrates a significance level of } 0.233 \text {, while the significance level for POBS remains } \\
\text { consistent at } 0.001 \text {. Correlations between MFA and POBS of } 0.23 \text { significant at } 0.001 \text {; } \\
\text { between MFA and Spirituality of } 0.162 \text { significant at } 0.004 \text {; and between POBS and } \\
\text { Spirituality of } 0.204 \text { significant at } 0.001 \text {. However regression analysis demonstrated that } \\
\text { a woman's perceived birth experience has more influence on maternal infant bonding } \\
\text { than spirituality. }\end{array}$ \\
\hline
\end{tabular}




\begin{tabular}{|c|c|c|c|}
\hline 6 & $\begin{array}{l}\text { - Emotional stressors } \\
\text { including feelings of } \\
\text { intense loneliness, } \\
\text { incarceration and } \\
\text { abject fear which } \\
\text { were exacerbated } \\
\text { by the participants' } \\
\text { sense of isolation } \\
\text { Protective impact } \\
\text { of strong kinship }\end{array}$ & $\begin{array}{l}\text { Adhering to spiritual and } \\
\text { cultural practices helps women } \\
\text { feel safe yet also restricts them. } \\
\text { Cultural taboos and perceived } \\
\text { influences of supernatural } \\
\text { agency can lead to emotional } \\
\text { distress } \\
\text { Childbirth experience is } \\
\text { connected to contextual } \\
\text { particularity and individual } \\
\text { values and beliefs. }\end{array}$ & $\begin{array}{l}\text { Honest to God, when I walked in to the place where you give labour, where they } \\
\text { inspected me. Straight, I walked out of there and it was like a depressing thing just come } \\
\text { over me instantly. It is so, it's like you can feel it's haunted, man, because I walked in } \\
\text { and, at the same time. . Yeah, I reckon this place is haunted. We all agreed. It's just } \\
\text { that feeling (Kerry). } \\
\text { She left here bright and happy and looking forward to the future, and came back like an } \\
\text { old woman, like a broken woman. That's what she was like. I really think it scarred her. I } \\
\text { think it's really brutal, it's shocking. It's disgusting, the way they were treating her } \\
\text { (Henry). (p61) }\end{array}$ \\
\hline
\end{tabular}


Table 4c. Synthesised theme: Honouring spiritual growth and wellbeing

\begin{tabular}{|c|c|c|c|}
\hline $\begin{array}{l}\text { STUDY } \\
\text { NO. }\end{array}$ & $\begin{array}{l}\text { STUDY AUTHOR } \\
\text { THEMES/INTEPRETATIONS }\end{array}$ & REVIEWERS INTERPRETATIONS & SUPPORTING DATA \\
\hline 1 & $\begin{array}{l}\text { Opportunity for spiritual } \\
\text { growth decreases stress } \\
\text { levels in the perinatal } \\
\text { period. }\end{array}$ & $\begin{array}{l}\text { Spiritual growth helps reduce stress levels in the } \\
\text { perinatal period and may influence emotional } \\
\text { morbidity postnatally. Opportunities for spiritual } \\
\text { growth requires attention by care providers. Care } \\
\text { providers need to promote self-care and help } \\
\text { women to maintain balance for spiritual } \\
\text { wellbeing. Interventions for facilitating spiritual } \\
\text { growth are of particular importance in women } \\
\text { experiencing high risk childbirth. }\end{array}$ & $\begin{array}{l}\text { The three specific categories of the HPLP II negatively correlated } \\
\text { with the composite score on the PSS, were spiritual growth, } \\
\text { interpersonal relations and stress management. This implies that } \\
\text { those with higher levels of perceived stress rated lower levels of } \\
\text { spiritual growth, interpersonal relations, and a decreased ability to } \\
\text { manage stress. P.42 }\end{array}$ \\
\hline 3 & $\begin{array}{l}\text { Experiences of childbirth are } \\
\text { existential and meaningful }\end{array}$ & $\begin{array}{l}\text { Childbirth is a significant time of personal } \\
\text { reflection for women and their relationships to } \\
\text { the world and the relationships around them - } \\
\text { past present and future. }\end{array}$ & $\begin{array}{l}\text { I needed much time for myself in the beginning, several hours a } \\
\text { day to think about myself, my parents, my childhood, and my } \\
\text { fiancé, there wasn't time for any intellectual work the first months. } \\
\text { I was completely absorbed by my life history and I thought more } \\
\text { about the past than the future (Lundgren and Wahlberg 1999, 15) } \\
\text { Very uncommunicative, enjoying myself and just being. Feeling } \\
\text { better and better. I don't think about anything special. Everything } \\
\text { is magic. (Lundgren and Wahlberg, 1999, 16) }\end{array}$ \\
\hline 4 & $\begin{array}{l}\text { CAM contributed to a } \\
\text { positive experience of } \\
\text { pregnancy and childbirth } \\
\text { facilitating personal growth, } \\
\text { fulfilment and recognition of } \\
\text { the emotional and spiritual } \\
\text { aspects of pregnancy and } \\
\text { childbirth. } \\
\text { CAM's potential is to } \\
\text { support transformation }\end{array}$ & $\begin{array}{l}\text { Personal and spiritual growth are interrelated } \\
\text { and connected with overall wellbeing and can be } \\
\text { supported with a variety of modalities that help } \\
\text { facilitate fulfilment in the childbirth experience. } \\
\text { Honouring these aspects of childbirth can lower } \\
\text { feeling of unpredictability. }\end{array}$ & $\begin{array}{l}\text { 'CAM] opens you up in a very powerful way to something that } \\
\text { your body is capable of [Riley] } \\
\text { 'It was a really difficult time. Having that space where we could } \\
\text { talk about it and also a place of deep relaxation as well that helped } \\
\text { us visualise where would we be when we had the baby. It sort of } \\
\text { took us out of the situation we were in and gave us tools that we } \\
\text { could use together. That was very transformative really' (Erin, 1st } \\
\text { interview) p70 } \\
\text { 'I was so at ease within myself and I was thinking I will be able to } \\
\text { do this, I believe in my ability to give birth without having all those } \\
\text { other things. I did it all by myself, just the breathing, just the }\end{array}$ \\
\hline
\end{tabular}




\begin{tabular}{|l|l|l|}
\hline & & $\begin{array}{l}\text { concentration and everything. Without the hypnotherapy I would } \\
\text { have definitely felt more out of control and a lot more scared and } \\
\text { not so confident in my own abilities'. (Alexandra, 1st interview) } \\
\text { p119 } \\
\text { 'it (labour and birth) was very easy. I was doing all the breathing } \\
\text { and I think that was why I was so calm and quiet. It was just } \\
\text { perfect. It was lovely and it was very positive and I have a warm } \\
\text { glow about it and it certainly left me, the birth left me quite happy } \\
\text { I would do it all again'. (Stephanie, 1st interview) }\end{array}$ \\
\hline
\end{tabular}




\section{Table 4d. Synthesised theme: Physical manifestations and embodiment}

\begin{tabular}{|c|c|c|c|}
\hline $\begin{array}{l}\text { STUDY } \\
\text { NO. }\end{array}$ & $\begin{array}{l}\text { STUDY AUTHOR } \\
\text { THEMES/INTEPRETATIONS }\end{array}$ & REVIEWERS INTERPRETATIONS & SUPPORTING DATA \\
\hline 1 & $\begin{array}{l}\text { High levels of stress meant } \\
\text { less spiritual growth. } \\
\text { Higher levels of stress led to } \\
\text { poor health promoting } \\
\text { behaviours in } 3^{\text {rd }} \text { trimester }\end{array}$ & $\begin{array}{l}\text { Rest and sleep matter for reducing stress in } \\
\text { complicated pregnancies and promoting } \\
\text { spiritual growth that in turn could be } \\
\text { associated with less depression. }\end{array}$ & $\begin{array}{l}\text { Higher levels of stress reported when inadequate rest periods. Need } \\
\text { for maintaining balance specifically with sleep deprivation } \\
\text { correlated with increasing parity. Lack of rest and sleep correlated } \\
\text { with poorer interpersonal relationships }(N=68, r=.300, p=.013) \text { and } \\
\text { less spiritual growth }(N=68, r=.249, p=.04) \text { and stress management } \\
(\mathrm{N}=68, r=.280, p=.021) \text {. Proper rest positively correlated with } \\
\text { spiritual growth, interpersonal relations and stress management. ( } p \text {. } \\
\text { 41) }\end{array}$ \\
\hline 2 & $\begin{array}{ll}\text { - } & \text { Physical malaise } \\
\text { - } & \text { Anxiety and } \\
& \text { sadness }\end{array}$ & $\begin{array}{l}\text { Spiritual connection to sadness, anxiety and } \\
\text { physical malaise during the postnatal period. }\end{array}$ & $\begin{array}{l}\text { 'She makes me feel very tired all the time, I have no energy and I } \\
\text { cannot look after my baby I have to ask my mother and she told me } \\
\text { she felt the same way as I do' p350 } \\
\text { "She may stay inside you for months...I do not know if she will ever } \\
\text { go." P351 }\end{array}$ \\
\hline 4 & $\begin{array}{l}\text { Physical connection and } \\
\text { touch }\end{array}$ & $\begin{array}{l}\text { Physical connection- on touch and } \\
\text { understanding and awareness of their bodies. }\end{array}$ & $\begin{array}{l}\text { 'I think because it's a hands on therapy, having that touch on the } \\
\text { body helps you to be in your body. Often before a treatment I might } \\
\text { have had lots of worries or concerns going on in my head so part of } \\
\text { the shiatsu treatment definitely helped me to stay in my body rather } \\
\text { than in my thoughts'. [Rachel, 2nd interview; p. 45]. }\end{array}$ \\
\hline
\end{tabular}




\section{CONTEXT}

(World of changing

systems e.g. policies,

models of care)

SPATIAL

(Felt-spaces and physical places for

birth e.g. hospital)

seen otherness, ineffability)
EMBODIED

(Felt-body)

RELATIONALITY (Being with others, mortals)

\section{TEMPORALITY}

(Kairos time) 


\section{Figure 2. PRISMA 2009 Flow Diagram}

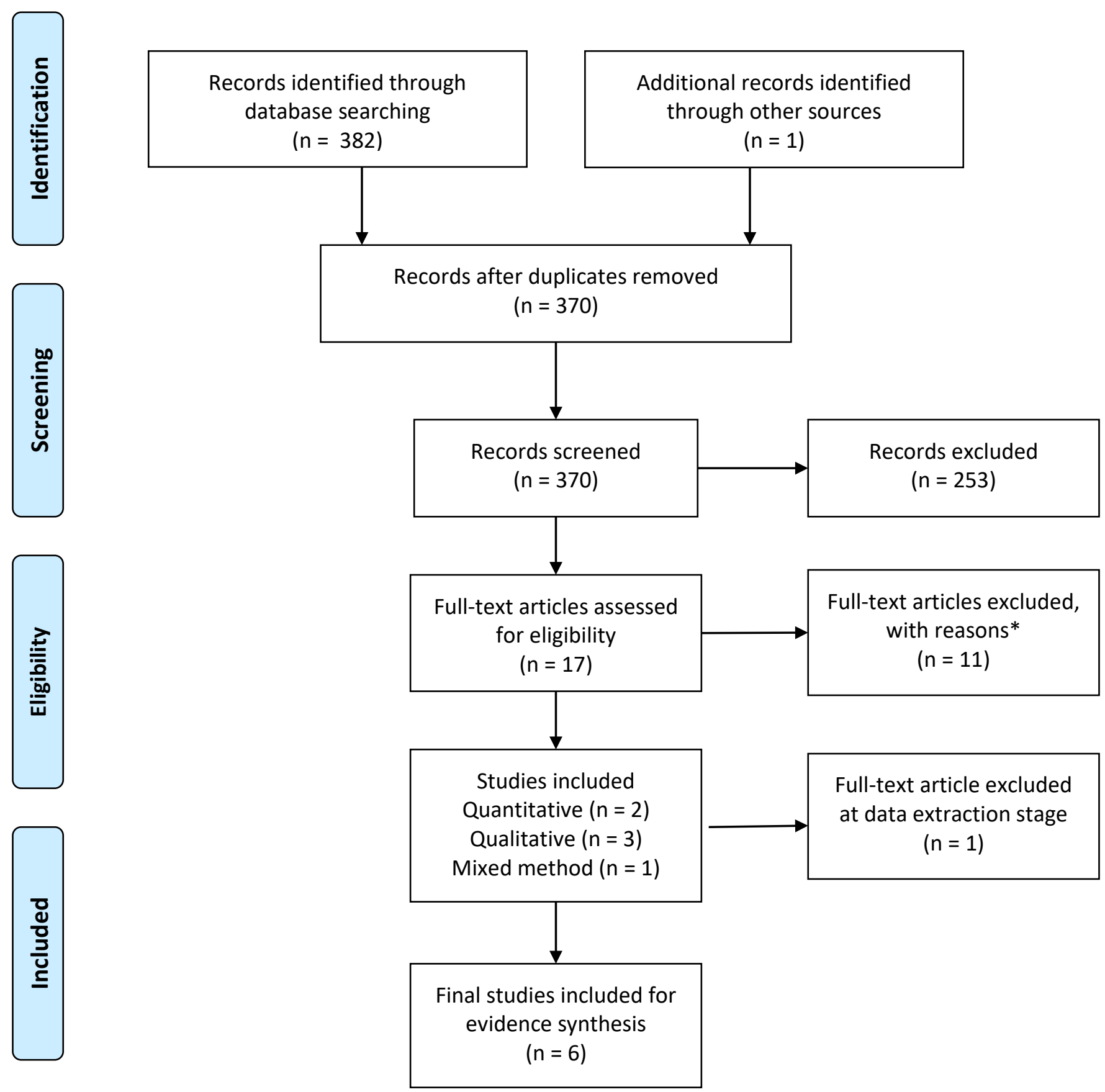

From: Moher D, Liberati A, Tetzlaff J, Altman DG, The PRISMA Group (2009). Preferred Reporting Items for Systematic Reviews and MetaAnalyses: The PRISMA Statement. PLoS Med 6(7): e1000097. doi:10.1371/journal.pmed1000097 
Figure 3. Conceptual model: Psychosocial and spiritual experiences around childbirth and relationship to potential postnatal mood disorders

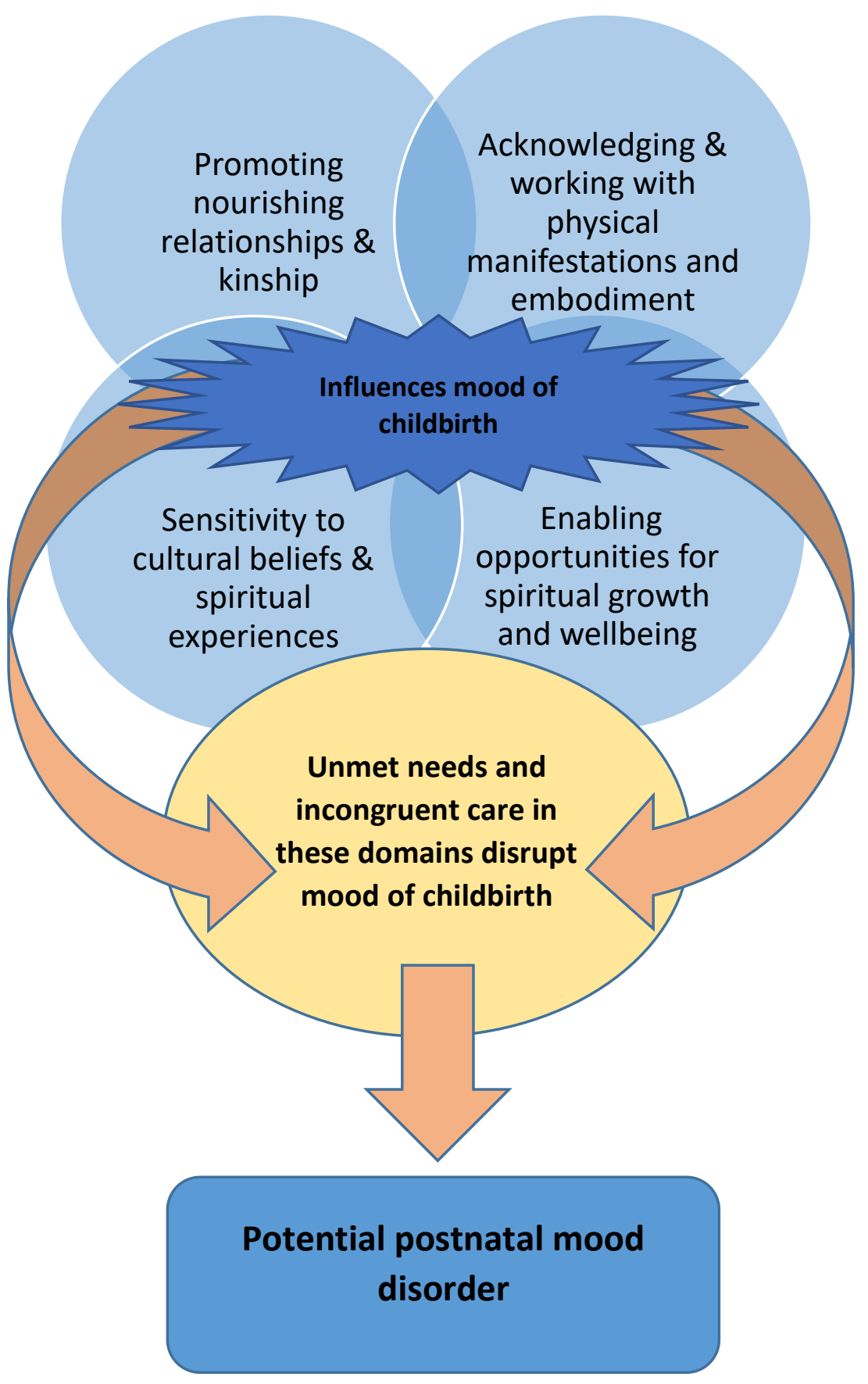

